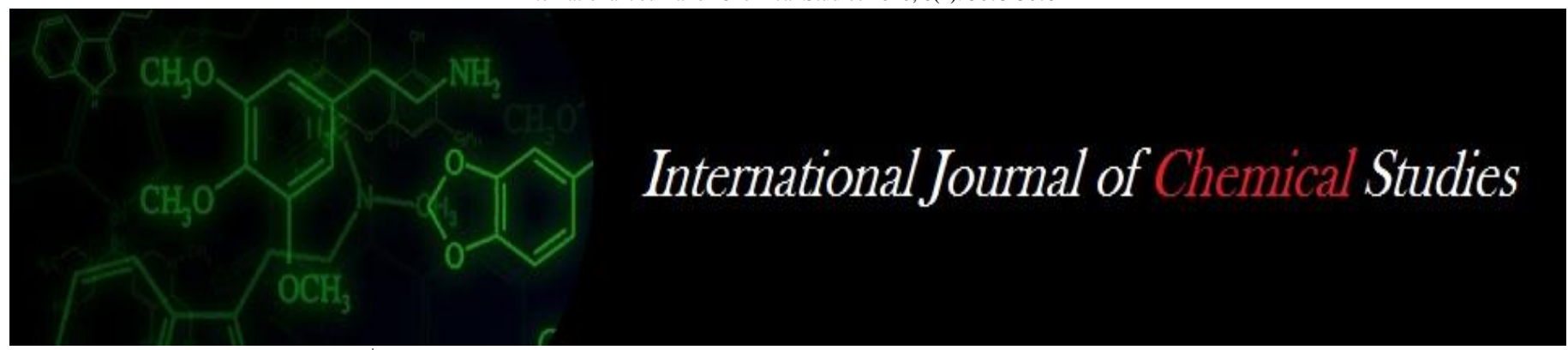

P-ISSN: 2349-8528

E-ISSN: 2321-4902

www.chemijournal.com

IJCS 2020; 8(1): 3073-3075

(C) 2020 IJCS

Received: 09-11-2019

Accepted: 13-12-2019

NK Roy

Department of Livestock

Production and Management,

College of Veterinary Sciences and

Animal Husbandry, Central

Agricultural University, Selesih,

Aizawl, Mizoram, India

\section{G Kalita}

Department of Livestock

Production and Management,

College of Veterinary Sciences and

Animal Husbandry, Central

Agricultural University, Selesih,

Aizawl, Mizoram, India

SN Abedin

Department of Veterinary

Physiology, College of Veterinary

Sciences and Animal Husbandry,

Central Agricultural University,

Selesih, Aizawl, Mizoram, India

\section{Paul}

Department of Veterinary Public Health \& Epidemiology, College of Veterinary Sciences and Animal Husbandry, Central Agricultural University, Selesih, Aizawl,

Mizoram, India

\section{DJ Talukdar}

Department of Animal

Reproduction, Gynaecology \& Obstetrics, College of Veterinary

Sciences and Animal Husbandry Central Agricultural University, Selesih, Aizawl, Mizoram, India

\section{Hmar}

Department of Livestock

Production and Management, College of Veterinary Sciences and

Animal Husbandry, Central

Agricultural University, Selesih,

Aizawl, Mizoram, India
Corresponding Author:

NK Roy

Department of Livestock

Production and Management,

College of Veterinary Sciences and

Animal Husbandry, Central

Agricultural University, Selesih,

Aizawl, Mizoram, India

\section{Effect of nutritional supplementation on biochemical profile of neonatal pig during pre- weaning period}

\author{
NK Roy, G Kalita, SN Abedin, D Paul, DJ Talukdar and L Hmar
}

DOI: https://doi.org/10.22271/chemi.2020.v8.i1au.8737

\begin{abstract}
The present study was conducted to know the effect of nutritional supplementation of neonatal pig on biochemical profile during pre-weaning period. A total of 72 number of Large White Yorkshire nursing piglets were utilized. Animals were randomly assigned into 4 equal groups; $\mathrm{T}_{1}, \mathrm{~T}_{2}, \mathrm{~T}_{3} \& \mathrm{C}$ (control). Weaning was done on day 28. The nutritional supplement containing bovine colostrum, egg yolk, probiotic, zinc oxide, chelated iron, dextrose powder etc. was fed orally twice daily with a gap of 6 hours up to 7 days to the piglet @ 2, 4, $6 \mathrm{ml} / \mathrm{kg}$ body wt./piglet of group $\mathrm{T}_{1}, \mathrm{~T}_{2}$ and $\mathrm{T}_{3}$ respectively. The control group was not fed any nutritional supplementation. Blood samples of piglets were analysed for Glucose, Total Protein (TP), Albumin, Aspartate Aminotransferase (AST), Alanine Aminotransferase (ALT), and Blood Urea Nitrogen $(B U N)$ at $7^{\text {th }}, 14^{\text {th }}$ \& $28^{\text {th }}$ day of experiment. The mean \pm SE of biochemical parameters in pre-weaning piglets were in normal ranged in group $T_{1}, T_{2}$ and $T_{3}$ and control group and significance difference were observed in glucose level on day 7 and albumin level on day 14 of preweaning. However, overall biochemical level at $28^{\text {th }}$ day was in normal range which indicates that supplementation of nutritional supplement during pre-weaning stage did not influence the biochemical parameters in pre-weaning pigs.
\end{abstract}

Keywords: Neonatal pig, Nutritional supplementation, biochemical parameters

\section{Introduction}

Livestock sector plays an important role in providing nutritious food, rich in animal protein and in providing family incomes and employment to millions of the people in India. Besides providing nutritional food in the form of meat, milk and egg, livestock is one of the best insurance against natural calamities like flood, drought, famine etc. Among the various livestock species, pig is one of the most important meat producing animals around the world [1]. Compared to other species, highest mortality (13\%) occurs during the neonatal phase (within 7 days postpartum) of piglet's life ${ }^{[2]}$. Feeding of young pig is one of the important factors affecting growth and survivability of young pigs ${ }^{[2,3]}$. Different techniques and managemental practices were developed in the last few decades to improve the efficiency of pig production system. Many studies have conducted to see the impact of supplementation of bovine colostrum, egg yolk immunoglobins, zinc oxide, probiotics, iron, dextrose powder etc. in weaned pigs. However, there is few information on effect of supplementation of these ingredients in a blended form on performance of neonatal pigs. High mortality rate of neonatal piglets (within 7 days postpartum), higher incidence of diarrhoea and poor growth during pre and post weaning periods are the major concern in pig husbandry ${ }^{[2]}$. Prime factors that might be responsible of neonatal mortality are low body energy reserves, poor birth weight, low intake of immunoglobulin immediately after birth and lack of required microclimatic condition for neonates ${ }^{[4]}$ which trigger many biochemical changes and further predisposing the piglet to pathogenic organisms ${ }^{[5,6]}$. Therefore, continuous monitoring of the health of the pigs becomes crucial. Blood biochemical parameters are routinely used to assess the health of the animals ${ }^{[6}$, 7]. Efforts are being made to supply extra source of nutrients like bovine colostrum, egg yolk protein, zinc oxide, iron etc. to the neonatal pig especially during the crucial few days of their life. In view of the above, the present study was planned to compare the health status of young pigs in terms of biochemical analysis during pre-weaning period, which were fed the Nutritional supplement. 


\section{Materials and Methods}

The study was carried out in the Pig Units of the Instructional Livestock Farm Complex, Department of Livestock Production and Management, College of Veterinary Sciences \& Animal Husbandry, Central Agricultural University, Selesih, Aizawl, Mizoram, India. For the purpose of the present study, 72 number of Large White Yorkshire nursing piglets were utilized. Considering the body weights, all the new born piglets in a litter (minimum litter size of 8 was considered for the study) were categorized into four groups viz. $\mathrm{T}_{1}$ (treatment 1 ), $\mathrm{T}_{2}$ (treatment 2 ), $\mathrm{T}_{3}$ (treatment 3 ) and $\mathrm{C}$ (control). The piglets were reared with their dam in the farrowing pen up to weaning ( 28 days of age), wherein piglets were allowed to suckle mother's colostrum/milk at free choice during the entire study period. Creep area with brooding facility was created inside the farrowing pen to maintain required temperature for the young piglets. Routine managemental practices like naval cord cutting, needle teeth grinding, iron injection etc. was followed as per standard procedure. The Nutritional supplement was fed orally twice daily with a gap of 6 hours up to 7 days to the piglet @ 2, 4, 6 $\mathrm{ml} / \mathrm{kg}$ body wt./piglet of $\mathrm{T}_{1}, \mathrm{~T}_{2}$ and $\mathrm{T}_{3}$ respectively. The control group was not fed any Nutritional supplementation. Pre-starter rations ${ }^{[8]}$ incorporating conventional feed ingredients along with skim milk powder was provided to the nursing piglets from $10^{\text {th }}$ day of age up to weaning.

Blood samples were collected from the anterior vena cava by using $5 \mathrm{ml}$ disposable syringes from all pigs under study on at $7^{\text {th }}, 14^{\text {th }} \& 28^{\text {th }}$ day of the experiment. Serum samples of piglets were analysed for important blood biochemical parameters like Glucose, Total Protein (TP), Albumin, Aspartate Aminotransferase (AST), Alanine Aminotransferase (ALT), and Blood Urea Nitrogen (BUN) by using Spectrophotometer (FUJIFILM analyser).

Data was analysed statistically as per the methods described by Snedecor and Cochran ${ }^{[9]}$.

\section{Results and Discussion}

The mean $\pm \mathrm{SE}$ of Biochemical parameters namely Blood
Glucose, Total Protein (TP), Albumin, Aspartate Aminotransferase (AST), Alanine Aminotransferase (ALT), and Blood Urea Nitrogen (BUN) have been presented in the Table 1 . The blood glucose levels $(\mathrm{mg} / \mathrm{dl})$ in piglets at day 7 , 14 , and 28 ranged from $109.50 \pm 2.90$ to $112.25 \pm 5.12$ in $\mathrm{T}_{1}$, $110.50 \pm 7.73$ to $133.25 \pm 10.36$ in $T_{2}, 116.0 \pm 5.70$ to $136.75 \pm 7.43$ in $\mathrm{T}_{3}$ and $110.25 \pm 4.61$ to $119.0 \pm 4.98$ in Control group. Statistical analysis revealed non-significant differences in blood glucose levels during different periods between treatment and control groups. However at day 7 , there was significantly $(\mathrm{P}<0.05)$ higher blood glucose level in $\mathrm{T}_{3}$ as compare to other groups that might be due to Zinc supplementation as reported by Borah et al., (2014) ${ }^{[10]}$ who found higher serum glucose concentration after supplementation of $500 \mathrm{ppm}$ of $\mathrm{Zn}$ in the diet of grower pigs. Similar findings were reported by Kaneko et al., (1997) [11] and Copper et al., (2014) ${ }^{[12]}$. The mean \pm SE of Total protein levels $(\mathrm{g} / \mathrm{dl})$ in pigs at day 7,14 , and 28 ranged from $4.48 \pm 0.25$ to $5.05 \pm 0.48$ in $\mathrm{T}_{1}, 4.65 \pm 0.26$ to $5.05 \pm 0.47$ in $\mathrm{T}_{2}$, $4.6 \pm 0.44$ to $4.98 \pm 0.30$ in $\mathrm{T}_{3}$ and $4.68 \pm 0.18$ to $5.53 \pm 0.24$ in Control group. Similar findings were reported by Copper et al., (2014) ${ }^{[12]}$ and Lovingson (2014) ${ }^{[13] .}$ Higher total protein $(\mathrm{g} / \mathrm{dl})$ levels than the present study was reported by Adesehinwa et al., (2008) [14]. The mean \pm SE of Albumin levels $(\mathrm{g} / \mathrm{dl})$ in pigs at day 7,14 , and 28 ranged from $2.78 \pm 0.51$ to $3.18 \pm 0.40$ in $\mathrm{T}_{1}, 3.0 \pm 0.29$ to $3.25 \pm 0.39$ in $\mathrm{T}_{2}$, $2.75 \pm 0.24$ to $4.33 \pm 0.27$ in $\mathrm{T}_{3}$ and $2.8 \pm 0.21$ to $3.2 \pm 0.31$ in Control group. The albumin $(\mathrm{g} / \mathrm{dl})$ levels in all the groups were in the ranges reported by Adesehinwa et al., (2008) ${ }^{[14]}$; Copper et al., (2014) ${ }^{[12]}$; Lovingson (2014) ${ }^{[13]}$. Statistical analysis revealed non-significant differences in Albumin levels between different treatment and control groups. However at day 14 albumin level was significantly $(\mathrm{P}<0.05)$ higher in $\mathrm{T}_{3}$ group as compared to other groups, which might be due to dietary supplementation of probiotics as reported by Dowarah et al., (2018) ${ }^{[15]}$ who found higher Albumin level after dietary supplementation of probiotics (Lactobacillus acidophilus \& Pediococcusacidilactici) in weaned pigs.

Table 1: Mean ( $\pm \mathrm{se})$ of biochemical parameters of lwy piglets under different treatment and control groups

\begin{tabular}{|c|c|c|c|c|c|c|}
\hline Parameters & $\begin{array}{c}\text { Age } \\
\text { (days) }\end{array}$ & Treatment- $1\left(\mathbf{T}_{1}\right)$ & $\begin{array}{c}\text { Treatment }-2 \\
\left(\mathbf{T}_{2}\right)\end{array}$ & $\begin{array}{c}\text { Treatment }-\mathbf{3} \\
\left(\mathbf{T}_{\mathbf{3}}\right)\end{array}$ & $\begin{array}{l}\text { Control } \\
\text { (C) }\end{array}$ & F Value \\
\hline \multirow{3}{*}{$\begin{array}{l}\text { Glucose } \\
\text { (mg/dl) }\end{array}$} & 7 & $109.50 \pm 2.90^{\mathrm{a}}$ & $110.50 \pm 7.73^{\mathrm{a}}$ & $136.75 \pm 7.43^{b}$ & $119.0 \pm 4.98^{\mathrm{a}}$ & $4.30^{*}$ \\
\hline & 14 & $112.0 \pm 3.42$ & $115 \pm 5.35$ & $116.0 \pm 5.70$ & $110.25 \pm 4.61$ & $0.30^{\mathrm{NS}}$ \\
\hline & 28 & $112.25 \pm 5.12$ & $133.25 \pm 10.36$ & $121.0 \pm 4.56$ & $110.50 \pm 2.06$ & $2.73^{\mathrm{NS}}$ \\
\hline \multirow{3}{*}{$\begin{array}{l}\text { Total protein } \\
\qquad(\mathrm{g} / \mathrm{dl})\end{array}$} & 7 & $4.48 \pm 0.25$ & $5.05 \pm 0.47$ & $4.88 \pm 0.27$ & $5.53 \pm 0.24$ & $1.81^{\mathrm{NS}}$ \\
\hline & 14 & $5.05 \pm 0.48$ & $4.65 \pm 0.26$ & $4.98 \pm 0.30$ & $4.68 \pm 0.18$ & $0.40^{\mathrm{NS}}$ \\
\hline & 28 & $4.98 \pm 0.52$ & $4.63 \pm 0.81$ & $4.6 \pm 0.44$ & $5.05 \pm 0.70$ & $0.14^{\mathrm{NS}}$ \\
\hline \multirow{3}{*}{$\begin{array}{l}\text { Albumin } \\
(\mathrm{g} / \mathrm{dl})\end{array}$} & 7 & $2.78 \pm 0.51$ & $3.0 \pm 0.29$ & $2.75 \pm 0.24$ & $3.2 \pm 0.31$ & $0.36^{\mathrm{NS}}$ \\
\hline & 14 & $2.88 \pm 0.38^{\mathrm{a}}$ & $3.25 \pm 0.39^{\mathrm{a}}$ & $4.33 \pm 0.27^{b}$ & $2.8 \pm 0.21^{\mathrm{a}}$ & $4.74 *$ \\
\hline & 28 & $3.18 \pm 0.40$ & $3.0 \pm 0.33$ & $4.28 \pm 0.51$ & $2.88 \pm 0.18$ & $2.91^{\mathrm{NS}}$ \\
\hline \multirow{3}{*}{ AST(IU/I) } & 7 & $35.75 \pm 2.59$ & $34.75 \pm 2.84$ & $36.0 \pm 3.76$ & $36.25 \pm 3.71$ & $0.04^{\mathrm{NS}}$ \\
\hline & 14 & $35.50 \pm 2.60$ & $35.75 \pm 2.93$ & $36.75 \pm 2.29$ & $32.25 \pm 4.11$ & $0.41^{\mathrm{NS}}$ \\
\hline & 28 & $36.25 \pm 4.71$ & $37 \pm 5.15$ & $37.75 \pm 2.29$ & $35.75 \pm 7.36$ & $0.03^{\mathrm{NS}}$ \\
\hline \multirow{3}{*}{ ALT(IU/l) } & 7 & $29.25 \pm 4.30$ & $32.50 \pm 3.57$ & $31.75 \pm 3.68$ & $29.00 \pm 2.04$ & $0.25^{\mathrm{NS}}$ \\
\hline & 14 & $28.00 \pm 2.35$ & $32.75 \pm 3.79$ & $30.50 \pm 2.40$ & $29.75 \pm 2.29$ & $0.50^{\mathrm{NS}}$ \\
\hline & 28 & $31.25 \pm 2.84$ & $27.75 \pm 4.80$ & $32.00 \pm 1.08$ & $30.75 \pm 1.31$ & $0.41^{\mathrm{NS}}$ \\
\hline \multirow{3}{*}{$\mathrm{BUN}(\mathrm{mg} / \mathrm{dl})$} & 7 & $7.80 \pm 1.55$ & $7.85 \pm 1.02$ & $8.50 \pm 0.79$ & $9.63 \pm 1.10$ & $0.55^{\mathrm{NS}}$ \\
\hline & 14 & $10.43 \pm 0.20$ & $9.48 \pm 1.17$ & $11.30 \pm 1.01$ & $9.73 \pm 0.91$ & $0.82^{\mathrm{NS}}$ \\
\hline & 28 & $12.25 \pm 1.19$ & $11.40 \pm 0.99$ & $10.73 \pm 0.67$ & $11.20 \pm 0.82$ & $0.46^{\mathrm{NS}}$ \\
\hline
\end{tabular}

*Significant $(\mathrm{P}<0.05)$, and NS-Non Significant, Note: Means bearing at least one common superscript in each row do not differ significantly

The mean \pm SE of AST (IU/l) levels in piglets at day 7, 14, and 28 ranged from $35.50 \pm 2.60$ to $36.25 \pm 4.71$ in $\mathrm{T}_{1}$,
$34.75 \pm 2.84$ to $37 \pm 5.15$ in $\mathrm{T}_{2}, 36.0 \pm 3.76$ to $37.75 \pm 2.29$ in $\mathrm{T}_{3}$ and $32.25 \pm 4.11$ to $36.25 \pm 3.71$ in control group. Similar 
findings were reported by Kaneko et al., (1997) ${ }^{[11]}$ and Copper et al.,(2014) [12], whereas higher values than the present study was reported by Vranesic et al., (1995) ${ }^{[16]}$ which might be due to individual variation. The mean \pm SE of ALT (IU/l) levels in piglets at day 7, 14, and 28 ranged from $28.00 \pm 2.35$ to $31.25 \pm 2.84$ in $\mathrm{T}_{1}, 27.75 \pm 4.80$ to $32.75 \pm 3.79$ in $\mathrm{T}_{2}, 30.50 \pm 2.40$ to $32.00 \pm 1.08$ in $\mathrm{T}_{3}$ and $29.00 \pm 2.04$ to $30.75 \pm 1.31$ in Control group. Similar findings were reported by Lovingson (2014) [13], however higher values than the present study was reported by Kaneko et al., (1997) ${ }^{[11]}$ and lower levels was reported by Vranesic et al., (1995) ${ }^{[16]}$ which might be due to individual variation. The mean \pm SE of BUN (IU/l) levels in piglets at day 7, 14, and 28 ranged from $7.80 \pm 1.55$ to $12.25 \pm 1.19$ in $\mathrm{T}_{1}, 7.85 \pm 1.02$ to $11.40 \pm 0.99$ in $\mathrm{T}_{2}$, $8.50 \pm 0.79$ to $11.30 \pm 1.01$ in $\mathrm{T}_{3}$ and $9.63 \pm 1.10$ to11.20 \pm 0.82 in Control group. Similar findings was reported by Kaneko et al., (1997) ${ }^{[11]}$, whereas higher values than the present study were reported by Adesehinwa et al.,(2008) ${ }^{[14]}$; Copper et al., (2014) ${ }^{[12]}$ and Lovingson (2014) ${ }^{[13]}$, which might be due to individual variation. Statistical analysis revealed nonsignificant differences in BUN levels levels during different periods between different treatment and control groups.

\section{Conclusion}

Hence, it can be concluded that Oral nutritional supplementation containing bovine colostrum, egg yolk, probiotics, dextrose, zinc oxide and chelated iron during neonatal period (birth to day 7) at the dose rate of 2 or 4 or 6 $\mathrm{ml} / \mathrm{kg}$ body weight twice daily didn't have adverse effect on biochemical parameters of young pigs during pre-weaning period (birth to 28 days of age).

\section{References}

1. McGlone JJ. The Future of Pork Production in the World: Towards Sustainable, Welfare-Positive Systems, Animals, 2013; 3:401-415.

2. Varley MA. The Neonatal Pig Development and Survival, CAB International Wallington, UK; 1995 1-16.

3. Mavromichalis I. Applied Nutrition for Young Pigs. CABI, Wallingford, Oxfordshire OX10 8DE, United Kingdom, 2006, 1-154.

4. Schinckel AP, Cabrera PASR, Boyd RD, Jungst S, Booher C, Johnston M, Einstein ME. The Professional Animal Scientist, 2007; 23:197-210.

5. Le Dividich J, Rooke JA, Herpin P. Nutritional and immunological importance of colostrum for the new-born pig. Journal of Agricultural Sciences. 2005; 143(6):469485.

6. Almond GW, Flowers WL, Batista L, Allaire S. Diseases of the reproductive system. In: Straw B E, Zimmerman J J, D'Allaire S, Taylor D J. Diseases of swine. 9. Ames: Blackwell publishing, 2006, 113-147.

7. Pal PS, Joshi R, Reddy MVR, Jain AP. Diagnostic yield of simple biochemical investigations amongst medical inpatients in teaching hospital. The journal of Mahatma Gandhi Institute of Medical Sciences. 2009; 14(2):40-46.

8. National Research Council (NRC). Nutritional Requirement of Swine., Subcommittee on Animal Nutrition, Board of Agriculture, NRC, National Academy Pres-2101 Constitution Avenue,; NW-Washington, DC, USA; 10th revised edition, 1998.

9. Snedecor, GW, Cochran WG. Statistical Methods. 8th ed. 1995; Oxford \& IBH Pub. Co., New Delhi.

10. Borah S, Sarmah BC, Chakravarty P, Naskar S, Dutta DJ, Kalita D. Effect of zinc supplementation on serum bio- chemicals in grower pig. J Appl. Anim Res. 2014; 42(2):244-248.

11. Kaneko JJ, Harvey JW, Bruss ML. Clinical Biochemistry of Domestic Animals. Harcourt Brace \& Company Asia PTE LTD, Singapore 5th Ednpp, 1997, 890-893.

12. Copper CA, Moraes LE, Murray JD, Owens SD. Hematologic and biochemical reference intervals for specific pathogen free 6-weeks-old Hampshire-Yorkshire crossbred pigs. J Anim. Sci. Biotechnol. 2014; 5:5.

13. Lovingson K, Performance of early weaned pigs under cage system of rearing. M.V.Sc. thesis Submitted to Central Agricultural University, Manipur, India, 2014.

14. Adesehinwa AOK, Dairo FAS, Olagbegi BS. Response of growing pigs to cassava peel based diets supplemented with avizyme1300: growth, serum and hematological indices. Bulg. J Agric. Sci. 2008; 14(5):491-499.

15. Dowarah R, Verma AK, Agarwal N, Singh P, Singh BR; Selection and characterization of probiotic lactic acid bacteria and its impact on growth, nutrient digestibility, health and antioxidant status in weaned piglets. PLOS ONE. (2018); 13(3):e0192978. https://doi.org/10.1371/journal.pone.0192978.

16. Vranesic N, Rupic V, Bacar-Huskic L, Bogdan S, Dominis-Kramaric M. Influence of multienzyme preparations on production results and on selected biochemical indicators in the blood of pigs from 10 to 24 kg body mass. Acta Vet. Brno. 1995; 64:235-242. 